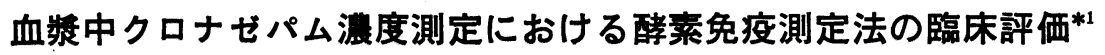

\author{
菱田 広, 高橋 朗, 佐治栄三*2, 武田明夫*3 \\ 国立名古屋病院薬剤科*2 \\ 同臨床脳波センター*3
}

\title{
Evaluation of the Enzyme Immunoassay for the Quantitation of Clonazepam Concentration in Plasma*1
}

\author{
HIRoshi Hishida, AKIRA TAKAhashi, EIZO SAJI*2, and AKIo TAKEDA*3 \\ Department of Pharmacy*2, and Clinical Encephalographic \\ Center, Department of Clinical Laboratory*3, Nagoya National Hospital
}

(Received September 26, 1986)

\begin{abstract}
We described the quantification of clonazepam in plasma using a semi-quantitative enzyme immunoassay reagent which rapidly identifies benzodiazepine overdosed in emergency cases. Since this reagent reacts with not only clonazepam but also several benzodiazepines and their metabolites, it is necessary to separate clonazepam from their metabolites before the measurement of its level. We excluded the interference of the clonazepam metabolites by using a sample preparation column. This method enabled the rapid quantification of clonazepam in plasma.

The between-run precision was established by 8 replicated analyses during 20 days, and the coefficient of variation values ranged from 8.0 to $14.8 \%$. Assay precision of this method were shown to be lesser than that of the high-performance liquid chromatography (HPLC) method. The lowest measurerable clonazepam concentration in plasma was about $10 \mathrm{ng} / \mathrm{ml}$ in the case of $0.5 \mathrm{ml}$ of sample used.Concentrations of plasma clonazepam in 29 patients determined by this method and HPLC method were compared and showed good correlations in the order of 0.917 in the linear regression analysis. We concluded that this method was sufficiently sensitive, convenient, and practically acceptable for the conventional therapeutic drug monitoring.
\end{abstract}

Keywords_-Enzyme Immunoassay; clonazepam ; Anticonvulsaut ; high-performance liquid chromatography; plasma concentration

\section{は じめに}

ベンゾジアゼピン系抗てんかん薬のクロナゼパムは, 幅広いスペクトルを持つ付加的な抗てんかん薬として広 く使用されている.またクロナゼパムの治療有効血中濃 度範囲は，De Silva らゆによれば 20〜 $50 \mathrm{ng} / \mathrm{ml}$ と報告 されており，さらにミオクロニーに対しては $15 \mathrm{ng} / \mathrm{ml}$ 以 上, 欠神発作では $20 \sim 30 \mathrm{ng} / \mathrm{ml}$, 他の発作型では $30 \mathrm{ng} /$ $\mathrm{ml}$ 以上で効果がみられるとの報告もある2). フェノバ ルビタール,フェニトインなどの他の抗てんかん薬治療

*1 本報は日本薬学会106年会（千葉市, 1986年 4 月） で発表.

*2,3 名古屋市中区三の丸 4 丁目 $1-1 ; 1-1$, Naka-ku Sannomaru 4-chome, Nagoya-shi, 460 Japan.
に, 薬物血中濃度測定が必要とされているのと同様に, クロナゼパムも薬物治療をより的確にする目的のため, 薬物血中濃度測定が必要と考える. これまでク口ナゼパ ムの血中濃度測定(3,4), ガスクロマトグラフィー（GL C) ${ }^{5,6)}$, 高速液体クロマトグラフィー (HPLC) $)^{7 \sim 10) な と ~}$ により行われている. しかしフェノバルビタール，フェ ニトインなどは, 酵素免疫測定法 (EIA), 蛍 光 偏光免 疫測定法により簡便に測定できる11のに比較して, クロ ナゼパムの血中濃度測定は試料の前処理が必要であった り, 測定に時間を要するなどまだ簡便な測定法はない。 したがって EIA による測定が可能になれば, 測定機器 の準備も容易であり, 測定時間も短縮することができ, クロナゼパムの血中濃度測定が簡便になると考えた.

最近, ベンゾジアゼピンの半定量用 EIA 試薬が市販 
されたが，この測定試薬は，ベンゾジアゼピンの過量投 与による副作用が疑われたときに，この副作用がベンゾ ジアゼピンによって引き起こされたものかどらかを緊急 に確認するために用いられるすのである. この EIA 試 薬は, 主としてジアゼパムを対象として開発されている が，他のベンゾジアゼピンに対しても交差反応性を有し ており，クロナゼパムに対しても反応性を示すと考えら れる. クロナゼパム以外の他のベンゾジアゼピンを服用 していない場合に，クロナゼパムの代謝物を除去すれ ばこの試薬を利用してクロナゼパムの濃度を測定する ことが可能になるのではないかと考えた. そこで使用さ れている薬物抗体のクロナゼパムに対する反応性, クロ ナゼパムの代謝物による影響の確認, およびその除去法 の検討を行い, この試薬を用いてクロナゼパムの濃度を 測定することができた。

さらに HPLCによるクロナゼパム測定值との比較検 討を行ったところ，高い相関が得られ，EIA によるク ロナゼパム測定が可能となったので報告する.

\section{実 験 の 部}

\section{1. 試薬 - 譏器}

EIA 試薬は EMIT 血清ベンゾジアゼピンアッセイキ ットを用い, 測定機器には Syva AC-5000を用いた. HPLC 装置は Waters 製 6000A 型ポンプ, 440型 UV 検出器, WISP710B オートサンプルプロセッサー, 730 型 Data module を用いた. 標準薬物試薬としてクロナ
ゼパム, アミノクロナゼパム, アセタミドクロナゼパム （日本ロシュ，住友製薬）を用いた。

\section{2. 薬物抗体のクロナゼパムおよびその代謝物に対す} る反性

EIA の薬物抗体のクロナゼパムおよびその代謝物に 対する反応性を検討した. クロナゼパムの濃度を $5 \mathrm{ng} /$ $\mathrm{ml} \sim 10 \mu \mathrm{g} / \mathrm{ml}$, 代謝物のアミノクロナゼパムの濃度を $10 \mathrm{ng} / \mathrm{ml} \sim 10 \mu \mathrm{g} / \mathrm{ml}$, アセタミドクロナゼパムを $1 \mu \mathrm{g} / \mathrm{ml}$ $\sim 10 \mu \mathrm{g} / \mathrm{ml}$ とし，EIA の測定に用いる希釈用緩衝液で 測定に影響しないと考えられる $0.055 \mathrm{M}$ Tris-塩酸緩衝 液（pH8.0）を用い調製した。薬物抗体に対する感受性 は, 各濃度試料 $0.3 \mathrm{ml}$ を用い, 測定試薬を加え 反応後 15秒から60秒間の $340 \mathrm{~nm}$ での吸光度変化量として表わ した。

\section{3. クロナゼパムと主要代謝物の分離}

血清試料の前処理カラムとしてよく利用されている Bond Elute $\mathrm{C}_{18}$ （充媜量 $100 \mathrm{mg}$ ）を用い,クロナゼパ ムと代謝物の分離法について検討した. クロナゼパムお よび代謝物のアミノクロナゼパムとアセタミドクロナゼ パムを，薬物を含まない血漿に各 $0.5 \mu \mathrm{g} / \mathrm{ml}$ になるよう に添加して試料とした. この試料 $1 \mathrm{ml}$ を Bond Elute $\mathrm{C}_{18}$ に保持させ, 蒸留水 $2 \mathrm{ml}$ にて 2 回洗浄 した後, ア セトニトリルと蒸留水の混液 $0.5 \mathrm{ml}$ にて 3 回溶出した. 使用した混液のアセトニトリルの容量比率は，20，25, $30 \%$ ものを調製し用いた. 前処理カラムのクロナゼパ ムおよび代謝物の残存率を，用いた三種混液各々につい
A

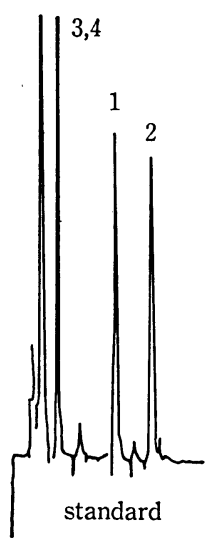

B

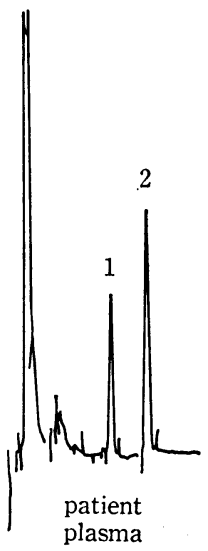

C

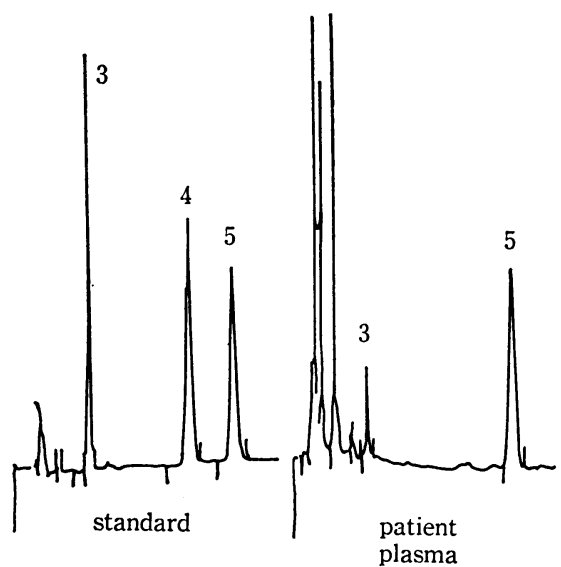

Fig. 1. Typical Chromatograms of Drug Standard and Serum Extracts A, B : clonazepam C, D : clonazepam metabolites peak 1 : Clonazepam $2:$ Nimetazepam (I.S.) $2:$ Aminoclonazepam 4 : Acetamidoclonazepam $5:$ Phenacetin (I.S.) 
て求めた。残存率は, 代謝物では各混液による溶出液中 の代謝物を測定し，またクロナゼパムは各混液による溶 出後, アセトニトリルで再度溶出させたときのアセトニ トリル中濃度より，添加したクロナゼパムおよび代謝物 の添加量に対する比率から求めた。 なおうロナゼパムお よび代謝物濃度測定は HPLCにて行った7).

Fig.1 亿，クロナゼパムとその代謝物の標準及び患者 血清試料のクロマトを示した. HPLCの条件として, カラムは NOVA PAK C 18 (Waters製)を用い，クロ ナゼパムの移動相としてアセトニトリル/D-4 試薬 $(2 / 5)$ 混液を用い，また代謝物の測定の移動相にはアセトニト リル/D-4 試薬 $(1 / 5)$ 混液を用いて分離を行った。 クロ ナゼパムおよび代謝物の検出波長は $254 \mathrm{~nm}$, 感度 0.005 aufs にて行った.

\section{EIA による クロナゼパム測定のための前処理操} 作

EIA によるクロナゼパム測定 のための 血漿前処理操 作は, 薬物抗体に対するクロナゼパムの感受性，および クロナゼパムと代謝物の分離の結果に基づき Fig. 2 に 示す手順で行った．血漿 $0.5 \mathrm{ml}$ を蒸留水にて 希釈 し， これを Bond Elute $\mathrm{C}_{18}$ カラムに通し，薬物を保持させ る. 蒸留水 $2 \mathrm{ml}$ にて 2 回洗浄した後, クロナゼパムの 代謝物を除去する目的で25\%アセトニトリル混液（アセ トニトリルと蒸留水 $1: 3$ 混液) $0.5 \mathrm{ml}$ にて 3 回洗浄す る. 次いでアセトニトリル $0.5 \mathrm{ml}$ にてクロナゼパムを溶 出させた後, 濃縮乾固する. 残渣を $0.055 \mathrm{M}$ Tris-塩酸 緩衝液 $\mathrm{pH} 8.0,0.4 \mathrm{ml}$ に溶解し, その $0.3 \mathrm{ml}$ を $\mathrm{EIA} の$ 試料とした。またクロナゼパムの検量線用標準夜は, EIA の血漿前処理操作で濃縮乾固した試料を $0.055 \mathrm{M}$ Tris-塩酸緩衝液にて溶解 していることより, クロナゼ パム標準品を $0.055 \mathrm{M}$ Tris-塩酸緩衝液にて, 血獎中ク ロナゼパムとして $10,25,50,75,100 \mathrm{ng} / \mathrm{ml}$ の濃度に 対応するよう調製したものを用いた.

\section{EIA によるクロナゼパム測定の同時 および測定} 間再現性

EIA によるクロナゼパム測定の再現性を検討するた め，薬物を含まない血漿にクロナゼパムを添加し，10〜 $100 \mathrm{ng} / \mathrm{m} 1$ の 5 段階の濃度をスパイクした試料を調製し た。これらの試料を用いた場合の同時再現性では各試料 を 5 回測定し，また測定間再現性は 20 日間にわたり，8 回二重測定を行い検討した.

6. EIA と HPLC によるクロナゼパム 服用患者血 泰中浱度の比較

当院脳波センター受診のクロナゼパム服用患者29例の 血墏中クロナゼパム濃度を, EIA と HPLCにて測定を
Plasma $0.5 \mathrm{ml}$

added $2.5 \mathrm{ml}$ distilled water

Applied to the Bond Elute C18 washed with $2 \mathrm{ml}$ distilled water 2 times

Elution of Clonazepam metabolites washed with $0.5 \mathrm{ml}$ acetonitrile : water (1:3), 3times

Elution of Clonazepam added $0.5 \mathrm{ml}$ acetonitrile

Evaporated

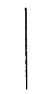

Residue

added $0.4 \mathrm{ml} 0.055 \mathrm{M}$ Tris- $\mathrm{HCl}$ buffer $(\mathrm{pH} 8.0$ )

Applied $0.3 \mathrm{ml}$ to EIA

Fig. 2. Schematic Representation of The Sample: Preparation Procedure from Plasma EIA : EMIT tox Serum Benzodiazepine Assay

Instrument : Syva AC-5000

Setting : wavelength $340 \mathrm{~nm}$, delay a $15-$ second and a 60-second measuement period.

行い, 両測定法の相関関係を調べ，比較検討を行った.

\section{結 果・考察}

\section{1. 薬物抗体のクロナゼパムおよびその代謝物に対す る反応性}

Fig. 3 亿示すように試料中の薬物濃度を横軸に，また 薬物抗体の反応性として, EIA 試薬と反応後 15 秒から 60秒間の吸光度変化量を縦軸にとった. その結果, ク口 ナゼパム 10 100 ng / $\mathrm{ml}$ の濃度範囲は, 治療濃度範囲を 含んでおり,クロナゼパムの測定が可能ではないかと考

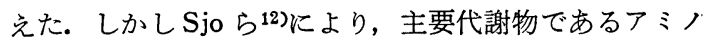
クロナゼパムの濃度がクロナゼパム濃度の $1 / 3 \sim 3$ 倍に なると報告されている，そこでクロナゼパムの主要代謝 物であるアミノクロナゼパムとアセタミドクロナゼパム のクロナゼパムに対する交差反応性も同様に検討した。 その結果, アセタミドクロナゼパムはほとんど交差反応 性がなく，測定には影響しないことが明らかとなった。 一方アミノクロナゼパムにはかなりの交差反応性が認め。 


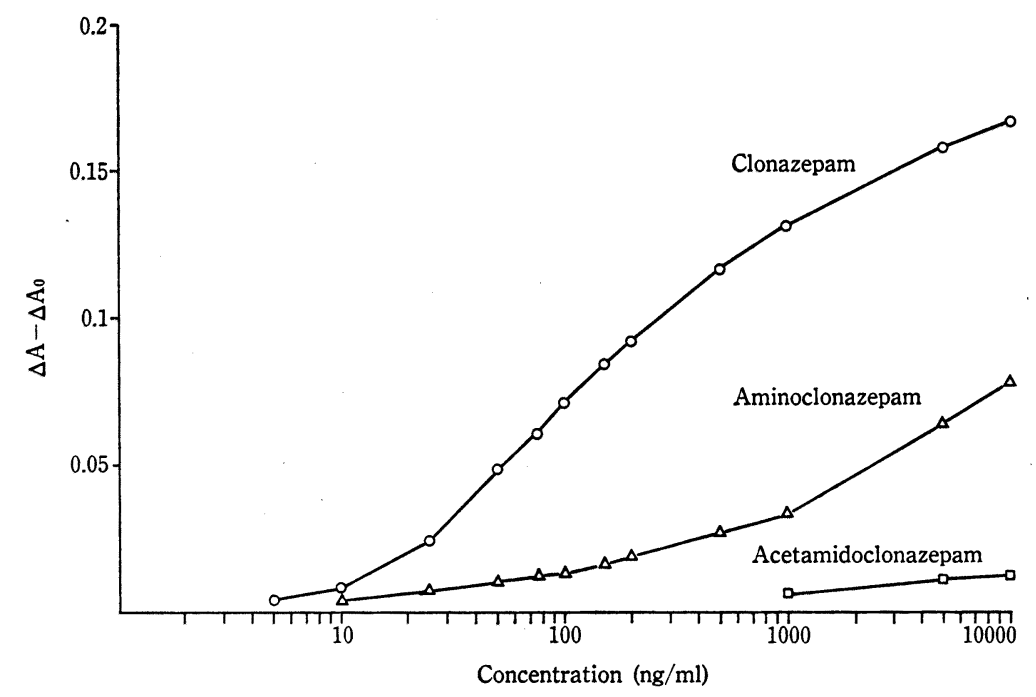

Fig. 3. Assay Reading of Clonazepam and It's Metabolites Against Concentration $\Delta \mathrm{A}-\Delta \mathrm{A}_{0}$ : The change in absorbance over a 60 -second measurement period after a 15 -second delay of reaction

られ,アミノクロナゼムパムは濃度 $25 \mathrm{ng} / \mathrm{ml}$ ではクロ ナゼパムとして $8.2 \mathrm{ng} / \mathrm{ml}, 50 \mathrm{ng} / \mathrm{ml}$ では $11.8 \mathrm{ng} / \mathrm{ml}$ の測定值となる結果が得られた。このことから EIA に よりクロナゼパムを測定するためには，クロナゼパムと 主要代謝物を分離する必要があることがわかった。

\section{2. クロナゼパムと主要代謝物の分離}

20\%アセトニトリル混液によるクロナゼパムと代謝物 の分離では, 代謝物が前処理カラムから十分に溶出され ボまた $30 \%$ アトトニトリル混液では代謝物はほぼ溶出 されるが，クロナゼパムも溶出される結果が得られた. しかし 25\%アセトニトリル混液を用いたときには， Table 1 に示すように， 3 回溶出を行うことにより，ク ロナゼパムは保持されたまま代謝物のアミノクロナゼパ ムの残存率が $0.3 \%$ ，アセタミドクロナゼパムでは $1.9 \%$ とほぼ分離することができた。

\section{EIA によるクロナゼパム測定の同時 および 測定}

\section{间再現性}

同時再現性と測定間再現性の結果を Table 2 に示した. EIA の同時再現性の CV 値は, $10 \mathrm{ng} / \mathrm{ml}$ の試料で 12.1 \%と比較的高い值を示したが, 25〜 $100 \mathrm{ng} / \mathrm{ml}$ の試料で は7.9\%以下の結果が得られた. また測定間再現性の CV 值は, $10 \mathrm{ng} / \mathrm{ml}$ の試料で $14.8 \%, 25 \sim 100 \mathrm{ng} / \mathrm{ml}$ の試料 では9.3\%以下の結果が得られた. 同様に行った HPLC の同時再現性の $\mathrm{CV}$ 值は2.0〜8:6\%を示し，また測定間 再現性では $10 \mathrm{ng} / \mathrm{ml}$ の試料 で $11.8 \%, 25 \sim 100 \mathrm{ng} / \mathrm{ml}$
Table 1. Absolute Recovery Values of Clonazepam and It's Metabolites Using Sample Preparation Column

Washing solvent; acetonitrile : water ( $1: 3)$

\begin{tabular}{|c|c|c|c|}
\hline Compound & 1 & ashing times & 3 \\
\hline \multirow{3}{*}{$\begin{array}{l}\text { Clonazepam } \\
\text { Amino- } \\
\text { clonazepam } \\
\text { Acetamido- } \\
\text { clonazepam }\end{array}$} & $99.7 \pm 4.2$ & $100.4 \pm 3.7$ & $99.8 \pm 1.3$ \\
\hline & $53.9 \pm 6.8$ & $5.0 \pm 0.3$ & $0.3 \pm 0.4$ \\
\hline & $58.5 \pm 5.8$ & $7.1 \pm 1.5$ & $1.9 \pm 0.3$ \\
\hline
\end{tabular}

Table 2. Within-run and Between-run Assay Precision Data for Clonazepam by EIA and HPLC

\begin{tabular}{cccrrr}
\hline \hline & $\begin{array}{c}\text { Spiked } \\
(\mathrm{ng} / \mathrm{ml})\end{array}$ & $\begin{array}{c}\text { E I A } \\
\text { Measured } \\
(\mathrm{ng} / \mathrm{ml})\end{array}$ & $\begin{array}{c}\text { C.V. } \\
(\%)\end{array}$ & $\begin{array}{r}\mathrm{H} \text { P L L C } \\
(\mathrm{ng} / \mathrm{ml})\end{array}$ & $\begin{array}{c}\text { C.V. } \\
(\%)\end{array}$ \\
\hline Within-run & 10 & 10.8 & 12.1 & 10.5 & 8.6 \\
$(\mathrm{n}=5)$ & 25 & 25.2 & 6.5 & 26.1 & 4.0 \\
& 50 & 50.4 & 5.7 & 48.6 & 3.5 \\
& 75 & 75.2 & 4.1 & 77.4 & 2.0 \\
& 100 & 98.2 & 7.9 & 103.8 & 2.4 \\
\hline Between-run & 10 & 10.5 & 14.8 & 10.4 & 11.8 \\
$(\mathrm{n=8})$ & 25 & 24.5 & 9.3 & 25.6 & 5.5 \\
& 50 & 50.4 & 8.0 & 52.5 & 4.7 \\
& 75 & 73.1 & 8.1 & 76.5 & 4.6 \\
& 100 & 97.7 & 8.8 & 102.1 & 4.6 \\
\hline
\end{tabular}

の試料では4.6〜5.5\%と，HPLC の方が EIA に比べ, 同時および測定間再現珄で若干よい結果が得られた。し かし EIA の測定間再現性は，治療域濃度範囲を含む25 


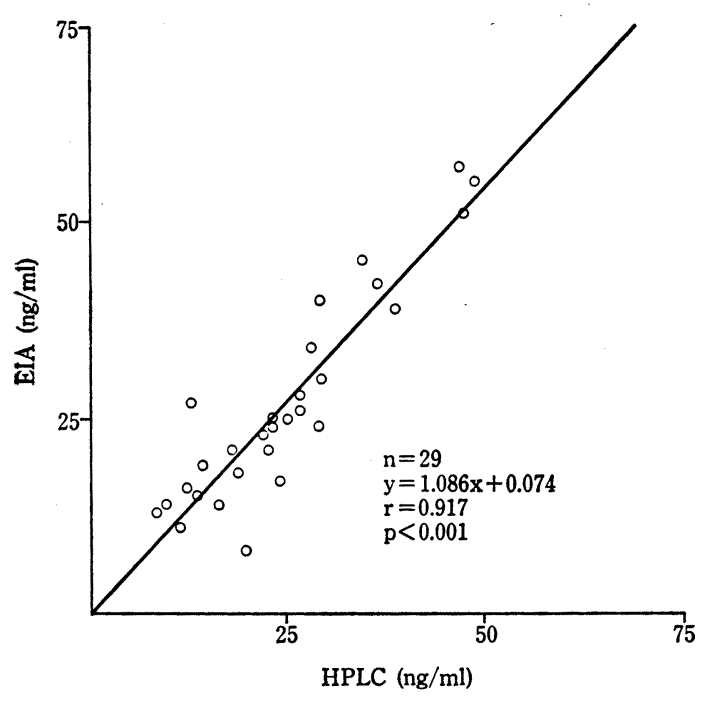

Fig. 4. Correlation of Plasma Clonazepam Concentrations Determined by EIA and HPLC

$\sim 100 \mathrm{ng} / \mathrm{ml}$ の試料の $\mathrm{CV}$ 值は10\%以下であることか ら, 臨床の場における薬物モニタリングにおいては許容 できる範囲の結果ではないかと考える.

4. EIA と HPLC によるクロナゼパム 服用息者血

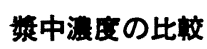

EIA と HPLC の両測定法による血墏中クロナゼパム 濃度測定値の比較を行ったところ, Fig. 4 亿示すように その回㷌直線は $\mathrm{y}=1.086 \mathrm{x}+0.074$ で, 相 関 係数 $\mathrm{r}=$ 0.917 の結果が得られ, 両測定法間に高い相関関係を認 めた. また血墏中クロナゼパム濃度測定値の平均は EIA では $27.0 \pm 13.1 \mathrm{ng} / \mathrm{ml}, \mathrm{HPLC}$ では $24.7 \pm 11.0 \mathrm{ng} / \mathrm{ml}$ であり, EIA の方が9.3\%高い測定值が得られる傾向が みられた。

以上のことから, EIA によるクロナゼパム濃度測定 は HPLC 飞比較し測定值が若干高くなることと, 再現 性がやや悪いとの結果が得られたが, 臨床の場における 薬物濃度測定法として十分利用できる範囲のものと考兄 る. また，前処理操作を除いたクロナゼパムの測定時間 が, HPLC では 1 試料15分要するのに比べ, EIA では
75秒程度で行らことができ, 測定時間の短縮化が可能と なること，また EIA では測定機器の準備が HPLC な どに比べ容易であることなどから， EIA によるクロナ ゼパム測定は簡便性の点で優れた方法と考えられる.

今回使用した EIA の薬物抗体は, ジフゼパムを対象 にしているため，クロナゼパムに対する反応性が不足し ていることもあり，よい測定再現性が得られなかったも のと考える. 今後, クロナゼパムを対象にした薬物抗体 が開発されれば，再現性も改善され，簡便な測定が可能 になると考える.

即辞本研究に対しご援助いただいた第一化学蒋品 （株），日本ロシニ（株），住友製薬（株）に深謝いたしま す.

\section{文献}

1) J.A.F. de Silva, C.V. Pulglisi, N. Munno: J. Pharm. Sci., 63, 520 (1974).

2) C.Y. Huang, J.G. Mcleod, D. Sampson, W. J.Hensley : Proc. Aust. Ass: Neurol., 10, 67 (1973).

3) M. J. Eadie, J. H. Tyrer : "Benzodiazepine anticonvulsants, Anticonvulsant Therapy Pharmacological Basis and Practice", Churchill Livingstone, 1980 p. 236-262.

4) M. J. Eadie : Drug, 27, 328 (1984).

5) P.M.Edelbroek, F.A. Dewolff : Clin.Chem., 24, 1774 (1978).

6) W. Loscher, F. J. O. Al-Tahan : Ther. Drug Monit., 5, 229 (1983).

7) 菱田 広, 竹田信也, 米島隆一, 武田明夫: 病院 緗学, 10,450 (1984).

8) E.H.Taylor, D.Sloniewsky, R.H.Gadsden : Ther. Drug Monit., 6, 474 (1984).

9) V.Rovei, M.Sanjuan : Ther. Drug Monit., 2, 283 (1980).

10) R.C. Williams, J.L. Viola : J. Chromatogr., 185, 505 (1979).

11）菱田 広, 竹田信也, 米島隆一, 武田明夫; 医 療, 38, 612 (1984).

12) O.Sjo, E.F.Hvidberg, J. Naestoft, M. Lund : Europ. J. Clin. Pharmacol., 8, 249 (1975). 